\title{
ANTWERP UNIVERSITY RADIOCARBON DATES III
}

\section{R VANHOORNE, M VAN STRYDONCK*, and A D DUBOIS}

Department of General Botany, State University Centre, Antwerp, Groenenborgerlaan 171, B-2020 Antwerpen, Belgium

The following list contains most of the measurements made during 1977, since our last list (R, 1977, v 19, p 383-388). The laboratory procedures used were those outlined in the previous date lists $(R, 1976$, v 18, p 151-160; R, 1977, op cit). Dates are calculated using ${ }^{14} \mathrm{C}$ half-life of $5568 \mathrm{yr}$ and errors are reported as one-standard deviation. The collagen extraction follows Longin (1970).

\section{ACKNOWLEDGMENTS}

Technical assistance by $\mathrm{F}$ Aerts is gratefully acknowledged. This work was supported by the FKFO (Fonds voor Kollektief Fundamenteel Onderzoek) Belgium. Sample descriptions are based on information supplied by submitters and collectors.

\section{SAMPLE DESCRIPTIONS}

I. GEOLOGIC SAMPLES

$$
\text { A. Belgium }
$$

ANTW-227. Leffinge 2

$3570 \pm 60$

Peat from layer $120 \mathrm{~cm}$ below surface $\left(51^{\circ} 8^{\prime} 40^{\prime \prime} \mathrm{N}, 2^{\circ} 52^{\prime} 15^{\prime \prime} \mathrm{E}\right)$. Coll Aug 1976 by R Paepe. Comment (RV): age corresponds roughly with expected age, and indicates peat growth halted at end of Sub-boreal.

\section{Lampernisse series}

ANTW-245. Lampernisse B68, 225-230

Wood and peat from layer $220 \mathrm{~cm}$ thick. Sample from 225 to $230 \mathrm{~cm}$ below surface $\left(51^{\circ} 02^{\prime} 10^{\prime \prime} \mathrm{N}, 2^{\circ} 45^{\prime} 10^{\prime \prime} \mathrm{E}\right)$. Coll June 1975 by C Baeteman. Comment (RV): submitter expected a date of $4200 \mathrm{BP}$, because sample was taken in lower half of layer, which began to develop at Atlanticum-Sub-Boreal transition.

\section{ANTW-244. Lampernisse B68, 490-514}

$5590 \pm 80$

Clayey peat sample from 490 to $514 \mathrm{~cm}$ below surface $\left(51^{\circ} 02^{\prime} 10^{\prime \prime} \mathrm{N}\right.$, $2^{\circ} 45^{\prime} 10^{\prime \prime} \mathrm{E}$ ). Coll June 1975 by C Baeteman. Comment (RV): Atlantic age was expected, because layer was included in Calais layer, underlying Holland peat.

ANTW-248. Lampernisse B71, 84

Peat from layer $200 \mathrm{~cm}$ thick at $84 \mathrm{~cm}$ below surface $\left(51^{\circ} 01^{\prime} 52^{\prime \prime} \mathrm{N}\right.$, $2^{\circ} 45^{\prime} 50^{\prime \prime}$ E). Coll 1975 by C Baeteman. Comment (RV): from sample belonging to top of Holland peat, we coll data of arrested peat development, which probably ranged from end of Sub-Boreal to 4th century AD.

* Koninklijk Instituut voor het Kunstpatrimonium, B-1040 Brussel, Belgium. 
ANTW-249. Lampernisse B71, 280

$4640 \pm 65$

Peat from layer $200 \mathrm{~cm}$ thick at $280 \mathrm{~cm}$ below surface $\left(51^{\circ} 01^{\prime} 52^{\prime \prime} \mathrm{N}\right.$, $2^{\circ} 45^{\prime} 50^{\prime \prime}$ E). Coll 1975 by C Baeteman. Comment (RV): dates beginning of peat formation in Belgian coastal plain and confirms opinion that peat development started at Atlantic-Sub-Boreal transition.

ANTW-250. Lampernisse B71, 370 $\quad \mathbf{5 1 0 0} \pm 140$

Peat at $370 \mathrm{~cm}$ below surface of layer $30 \mathrm{~cm}$ thick $\left(51^{\circ} 01^{\prime} 52^{\prime \prime} \mathrm{N}\right.$, $2^{\circ} 45^{\prime} 50^{\prime \prime} \mathrm{E}$ ). Coll June 1975 by C Baeteman. Comment (RV): date of top of peat layer, included in Calais layer, reveals that peat formation stopped in last phase of Atlantic period, as expected.

ANTW-251. Lampernisse B 71, $400 \quad 5310 \pm 190$

Peat at $400 \mathrm{~cm}$ below surface of layer $30 \mathrm{~cm}$ thick $\left(51^{\circ} 01^{\prime} 52^{\prime \prime} \mathrm{N}\right.$, $2^{\circ} 45^{\prime} 50^{\prime \prime}$ E). Coll June 1975 by C Baeteman. Comment (RV): date of base of peat layer included in Calais layer, reveals that peat formation began in Atlantic period, as expected. According to dates ANTW-250 and -251, peat growth occurred quickly, mean rate being ca $1.4 \mathrm{~mm} \mathrm{yr}^{-1}$.

ANTW-214. Lampernisse 93a, Point 189

$3110 \pm 80$

Wood from a pine trunk lying horizontally in peat layer of Belgian coastal plain $170 \mathrm{~cm}$ below surface $\left(51^{\circ} 01^{\prime} 20^{\prime \prime} \mathrm{N}, 2^{\circ} 49^{\prime} 50^{\prime \prime} \mathrm{E}\right)$. The trunk contained 89 annual rings and was divided into 3 secs for determination. Coll 1951 by R Vanhoorne.

\begin{tabular}{lccrrr}
\multicolumn{5}{c}{ TABLE 1 } & \\
\hline Description & Date yr BP & \multicolumn{2}{c}{ Recalculated date } & $\mathrm{x}-\overline{\mathrm{x}}$ & $(\mathrm{x}-\overline{\mathrm{x}})^{2}$ \\
\hline Outer 17 rings & $3040 \pm 50$ & $(3040-9) \pm 50$ & $3031 \pm 50$ & 83 & 6889 \\
Intermediate 27 rings & $3150 \pm 60$ & $(3150-31) \pm 60$ & $3119 \pm 60$ & 5 & 25 \\
Inner 45 rings & $3260 \pm 55$ & $(3260-67) \pm 55$ & $3193 \pm 55$ & 79 & 6241 \\
\hline
\end{tabular}

Comment (RV\&MVS): assuming that each date can be related to central ring of each sec, we can recalculate the results in function of the outermost annual ring (Table 1 ). With recalculated dates the error of chemistry can be rechecked (R, 1976, v 18, p 151-152).

mean value $=\overline{\mathrm{X}}=\frac{\sum \mathrm{X}}{\mathrm{n}}=3114 \mathrm{yr}$

one standard deviation: $\mathrm{s}=\sqrt{\frac{(\mathrm{x}-\overline{\mathrm{x}})^{2}}{\mathrm{n}-\mathrm{l}}}=81 \mathrm{yr}$

error $^{2}$ measured $=$ error $^{2}{ }_{\text {chemistry }}+$ error $^{2}{ }_{\text {counting }} \quad$ (Wyld, 1970)

error $_{\text {chem istry }}=\sqrt{\text { error }^{2} \text { measured }- \text { error }^{2}{ }_{\text {counting }}}$

mean error due to counting statistics alone: $55 \mathrm{yr}$

error $_{\text {chemistry }}=\sqrt{81^{2}-55^{2}}=59 \mathrm{yr}$

which implies a reduction of $54 \%$ 
Date fits well with peat age deducted from pollen diagram (Stockmans \& Vanhoorne, 1954, p 136), in which end of Sub-Boreal is indicated between 170 to $160 \mathrm{~cm}$ below surface. No Fagus was found at $1.70 \mathrm{~m}$, while $10 \mathrm{~cm}$ higher, Fagus appears, for 1st time in pollen diagram, continuing its presence to top of peat in an uninterrupted curve, attaining $30 \%$ at top.

\section{Zandvoorde series}

ANTW-228. Zandvoorde 9

Peat from layer $150 \mathrm{~cm}$ thick, at $450 \mathrm{~cm}$ below surface $\left(51^{\circ} 12^{\prime} 30^{\prime \prime} \mathrm{N}\right.$, $2^{\circ} 58^{\prime} 30^{\prime \prime}$ E). Coll Aug 1976 by C Baeteman. Comment (RV): date reveals that peat growth halted at very end of Sub-Boreal, i.e. 500 years later than at Leffinge (ANTW-227).

ANTW-Zandvoorde 11

$6750 \pm 125$

Peat layer $950 \mathrm{~cm}$ below surface $\left(51^{\circ} 12^{\prime} 30^{\prime \prime} \mathrm{N}, 2^{\circ} 58^{\prime} 30^{\prime \prime} \mathrm{E}\right)$. Coll Aug 1976 by C Baeteman. Comment (RV): date reveals that peat, embedded in Calais layer, developed in Atlantic period, which corresponds with opinion that Calais layer was deposited by Calais transgression in Atlantic period.

\section{Paal series}

ANTW-254. Paal 1-C, 60-65

$9400 \pm 200$

Peat, 60 to $65 \mathrm{~cm}$ below surface $\left(51^{\circ} 03^{\prime} 34^{\prime \prime} \mathrm{N}, 05^{\circ} 09^{\prime} 41^{\prime \prime} \mathrm{E}\right)$. Coll Sept 1975 by L Beyens \& R Vanhoorne. Comment (LB): date agrees with Pre-Boreal age, indicated by pollen analysis. Vegetation type was a Betula-Pinus forest.

ANTW-255. Paal 1-C, 85-90

$$
10,120 \pm 155
$$

Peat, 85 to $90 \mathrm{~cm}$ below surface $\left(51^{\circ} 03^{\prime} 34^{\prime \prime} \mathrm{N}, 05^{\circ} 09^{\prime} 41^{\prime \prime} \mathrm{E}\right)$. Coll Sept 1975 by L Beyens \& R Vanhoorne. Comment (LB): no pollen was found in sample. Palynologic analysis of sec between 80 and $70 \mathrm{~cm}$ points to younger Dryas period.

\section{Wortel series}

Peat layer 0 to $435 \mathrm{~cm}$ below surface $\left(4^{\circ} 47^{\prime} 36^{\prime \prime} \mathrm{N}, 51^{\circ} 23^{\prime} 52^{\prime \prime} \mathrm{E}\right)$. Coll Feb 1977 by L Beyens, C Verbruggen, and M Van Strydonck.

ANTW-261. Wortel 1, 85-95

$3990 \pm 130$

Sample from 85 to $95 \mathrm{~cm}$ below surface.

ANTW-262. Wortel 1, 125.140

$4680 \pm 75$

Sample from 135 to $140 \mathrm{~cm}$ below surface.

ANTW-263. Wortel 1, 185-190

$5980 \pm 80$

Sample from 185 to $190 \mathrm{~cm}$ below surface.

ANTW-264. Wortel 1, 275-280

$7950 \pm 95$

Sample from 275 to $280 \mathrm{~cm}$ below surface. 
ANTW-265. Wortel 1, 355-360

$9060 \pm 115$

Sample from 355 to $360 \mathrm{~cm}$ below surface.

General Comment (LB): date of ANTW-261 confirms Sub-Boreal age. At $80 \mathrm{~cm}$ pollen diagram shows 1st appearance of Cerealia. No typical Atlantic sequence is present: maximum 15\% mixed oak forest, probably caused by over-representation of Alnus and Betula, due to ecologic conditions. ANTW-262 date is difficult to confirm but should be early SubBoreal age. ANTW-263 indicates Atlantic age. ANTW-265 date fits well in pollen diagram: $70 \%$ Pinus and expansion of Corylus reveals a Boreal age. Elements of mixed oak forest appears in very small quantities.

\section{Bergen-Bruggen series}

Peat layer 100 to $330 \mathrm{~cm}$ below surface $\left(51^{\circ} 26^{\prime} 23^{\prime \prime} \mathrm{N}, 4^{\circ} 45^{\prime} 47^{\prime \prime} \mathrm{E}\right)$. Coll June 1977 by L Beyens, C Verbruggen, and M Van Strydonck.

ANTW-271. Bergen-Bruggen, 195

$7060 \pm 90$

Wood, embedded in peat $195 \mathrm{~cm}$ below surface.

ANTW-274. Bergen-Bruggen, 210-230

$8420 \pm 110$

Peat, 210 to $230 \mathrm{~cm}$ below surface.

ANTW-275. Bergen-Bruggen, 230-250

$8850 \pm 120$

Peat, 230 to $250 \mathrm{~cm}$ below surface.

ANTW-272. Bergen-Bruggen, 250-270

$9510 \pm 175$

Peat, 250 to $270 \mathrm{~cm}$ below surface.

ANTW-276. Bergen-Bruggen, 270-290

$9390 \pm 100$

Peat, 270 to $290 \mathrm{~cm}$ below surface.

ANTW-270. Bergen-Bruggen, 290-310

$9510 \pm 200$

Peat, 290 to $310 \mathrm{~cm}$ below surface.

ANTW-273. Bergen-Bruggen, 310-330

$10,230 \pm 320$

Peat, 310 to $330 \mathrm{~cm}$ below surface.

General Comment (LB): dates seem acceptable in light of present knowledge of Wortel-1 peat sec. ANTW-272 date is slightly too old, but can still fit in series when error is considered. Pollen analysis of sec is under study.

ANTW-204. Rijkevorsel R/2

$1100 \pm 240$

Soil, 45 to $55 \mathrm{~cm}$ below surface $\left(51^{\circ} 20^{\prime} 39^{\prime \prime} \mathrm{N}, 4^{\circ} 45^{\prime} 34^{\prime \prime} \mathrm{E}\right)$. Coll May 1976 by J Maes. Comment (CV \& MVS): extracted humic acid was dated, indicating beginning of formation of soil plagging.

\section{Deinze series}

ANTW-241. Deinze-market place $\quad \mathbf{8 6 0} \pm \mathbf{5 0}$

Sample from infilled ditch at market place of Deinze, $120 \mathrm{~cm}$ below surface $\left(50^{\circ} 59^{\prime} 18^{\prime \prime} \mathrm{N}, 3^{\circ} 3^{\prime} 53^{\prime \prime} \mathrm{E}\right)$. Coll 1976 by C Verbruggen. Com- 
ment $(\mathrm{CV})$ : date agrees with pollen analysis of adjoining buried soil surface.

\section{ANTW-256. Deinze 3}

$6380 \pm 135$

Wood, $700 \mathrm{~cm}$ below surface (50 59' 32" N, 3० 32' 32" E). Coll 1977 by $\mathrm{C}$ Verbruggen.

ANTW-257. Deinze 2

Peat, 640 to $660 \mathrm{~cm}$ below surface $\left(50^{\circ} 59^{\prime} 32^{\prime \prime} \mathrm{N}, 3^{\circ} 32^{\prime} 32^{\prime \prime} \mathrm{E}\right)$. Coll 1977 by C Verbruggen.

ANTW-258. Deinze 1

Shells, 610 to $640 \mathrm{~cm}$ below surface $\left(50^{\circ} 59^{\prime} 32^{\prime \prime} \mathrm{N}, 3^{\circ} 32^{\prime} 32^{\prime \prime} \mathrm{E}\right)$. Coll 1977 by C Verbruggen.

General Comment (CV \& MVS): pollen analysis, showing Atlantic spectra, confirms dates of Deinze 2 and 3. The date of Deinze 1 is too old, as expected (Thommeret, 1976; Keith \& Anderson, 1964; Broecker, 1964).

\section{ANTW-201. Mammoth tusk, Dendermonde \\ $29,880 \pm 930$}

Collagen extract of a mammoth tusk $1000 \mathrm{~cm}$ below surface in coarse sand $\left(51^{\circ} 02^{\prime} 08^{\prime \prime} \mathrm{N}, 04^{\circ} 05^{\prime} 18^{\prime \prime} \mathrm{E}\right)$. Coll 1970 by H De Potter. Comment $(\mathrm{RV})$ : age is younger than expected, because sediments bearing mammalia bones were placed (De Moor, 1974) at beginning of Pleniglacial A $(72,000$ to $60,500 \mathrm{BP})$. However, environmental conditions of end of Denekamp interstadial, corresponding with obtained date, were favorable to proliferation of mammoth.

\section{Ipenrooi-Hoogstraten series}

ANTW-209. Ipenrooi 2', 60-70

$\mathbf{7 8 8 0} \pm \mathbf{8 5}$

Peat from layer 60 to $70 \mathrm{~cm}$ below surface $\left(51^{\circ} 29^{\prime} 50^{\prime \prime} \mathrm{N}, 4^{\circ} 45^{\prime} 14^{\prime \prime}\right.$ E). Coll Oct 1975 by J Janssens \& R Vanhoorne. Comment (RV): date is 3500 years too young because pollen diagram reveals pine phase of Alleröd, characterized by dominance of pine over birch in a woody landscape, in which no thermophilous trees were growing. Rejuvenation is certainly due to contamination by younger plant material, observable in microscopic secs of the wood, perforated by later growing water plant roots.

ANTW-208. Ipenrooi 2', 105

$9130 \pm 25$

Peat from laver $105 \mathrm{~cm}$ below surface $\left(51^{\circ} 29^{\prime} 50^{\prime \prime} \mathrm{N}, 4^{\circ} 45^{\prime} 14^{\prime \prime} \mathrm{E}\right)$. Coll Oct 1975 by J Janssens and R Vanhoorne. Comment (RV): date does not correspond with age deduced from pollen diagram. Palynoflora indicates open birch wood without thermophilous trees existing at beginning of Alleröd; date ca 11,800 yr вp was expected.

\section{ANTW-246. Wambeek B2/25 $\quad 6520 \pm 100$}

Peat with clay and lime $450 \mathrm{~cm}$ below surface $\left(50^{\circ} 51^{\prime} 30^{\prime \prime} \mathrm{N}, 4^{\circ} 10^{\prime}\right.$ 00" E). Coll Feb 1977 by W Huybrechts. Comment (RV): scarcity of 
pollen grains in sediment prevents confirmation of date of 1st half of Atlantic period. But palynoflora indicates a woody landscape, in which Pinus, Alnus, Betula, and Corylus were growing.

ANTW-247. St-Martens Bodegem B2/28 $\quad 11,240 \pm 90$

Peat in clay and lime $460 \mathrm{~cm}$ below surface $\left(50^{\circ} 51^{\prime} 30^{\prime \prime} \mathrm{N}, 2^{\circ} 13^{\prime}\right.$

00" E). Coll Feb 1977 by W Huybrechts. Comment (RV): palynoflora, containing $40 \%$ of arboreal pollen, points to open park landscape in which Betula was dominant. Salix, Corylus, and Pinus completed the forest vegetation. Based on the opinion that 2nd half of Alleröd was characterized by dense Pinus-Betula wood, date seems to be ca $200 \mathrm{yr}$ too young.

ANTW-285. Ruisbroek 233 P1- $\mu 8$

$4440 \pm 80$

Peat and wood at $247 \mathrm{~cm}$ below surface $\left(51^{\circ} 05^{\prime} 00^{\prime \prime} \mathrm{N}, 4^{\circ} 21^{\prime} 16^{\prime \prime} \mathrm{E}\right)$. Coll 1973 by J Geys. Comment (RV): Sub-Boreal date corresponds with expectations of submitter. Pollen spectrum shows dominance of Quercetum mixtum with high percentages of Alnus and ca $10 \%$ Corylus. Only few Ericales and Gramineae have been found. Fagus was totally absent. Therefore it is hard to conclude on basis of pollen-analysis that peat layer was deposited in Atlanticum or Sub-Boreal.

\section{Cairngorm Estate series}

ANTW-220. Site 10, Sample 15

$6210 \pm 120$

Trunk from pine stump from eroded blanket bog between Allt $\mathrm{a}^{\prime}$ Choire Chais and Caochan Dubh a Chadha; alt, $+570 \mathrm{~m}\left(57^{\circ} 08^{\prime} 09^{\prime \prime} \mathrm{N}\right.$, $\left.3^{\circ} 40^{\prime} 44^{\prime \prime} \mathrm{W}\right)$. Coll 1975 by L Beyens and D K Ferguson. Comment (DKF): growth was slow in 1st $30 \mathrm{yr}$, growth rings averaging no more than $0.7 \mathrm{~mm} / \mathrm{yr}$. Thereafter girth increased fairly rapidly (average growth ring: $1.85 \mathrm{~mm}$ ) and after $45 \mathrm{yr}$, trunk diam was $8 \mathrm{~cm}$. Age determination is based on cross-sec covering complete time span.

ANTW-221. Site 11, Sample 16

$4150 \pm 70$

Trunk from pine stump in eroded blanket bog above Coachan Dubh $\mathrm{a}^{\prime}$ Chadha; alt, $+545 \mathrm{~m}\left(57^{\circ} 08^{\prime} 13^{\prime \prime} \mathrm{N}, 3^{\circ} 40^{\prime} 51^{\prime \prime} \mathrm{W}\right)$. Coll 1975 by $\mathrm{L}$ Beyens and $\mathrm{D} \mathrm{K}$ Ferguson. Comment (DKF): tree just managed to survive, for growth rings averaged $0.3 \mathrm{~mm} / \mathrm{yr}$ in 1 st $70 \mathrm{yr}$. Between 65 to $75 \mathrm{yr}$, a number of wider growth rings of up to $2 \mathrm{~mm}$ are present, but thereafter, width decreases again. The tree lived at least $90 \mathrm{yr}$. Age determination is based on cross-sec covering complete time span.

ANTW-222. Site 22-1, Sample 17

$1190 \pm 55$

Root from pine stump $30 \mathrm{~cm}$ from surface of accumulation of peat $1.5 \mathrm{~m}$ thick overlying river gravel Caochan Dugh a' Chadha; alt, $+530 \mathrm{~m}$ $\left(57^{\circ} 08^{\prime} 13^{\prime \prime} \mathrm{N}, 3^{\circ} 41^{\prime} 11^{\prime \prime} \mathrm{W}\right)$. Coll 1975 by L Beyens and D K Ferguson. Comment (DKF): although pine disappeared from surrounding slopes 
thousands of yr previously, this sheltered valley above tree-line was able to support a number of individual trees up to the present.

ANTW-236. Site 22-2, Sample 18

$5690 \pm 60$

Root from pine stump at base of accumulation of peat $1.5 \mathrm{~m}$ thick overlying river gravel Caochan Dubh a Chadha; alt, $+530 \mathrm{~m}\left(57^{\circ} 08^{\prime}\right.$ 13" N, $\left.3^{\circ} 41^{\prime} 11^{\prime \prime} \mathrm{W}\right)$. Coll 1975 by L Beyens and D K Ferguson. Comment (DKF): date indicates Dubh $\mathrm{a}^{\prime}$ Chadha stream was already in existence in Atlantic times.

\section{ANTW-259. Site 12-1, Sample 19}

$3940 \pm 95$

Trunk from pine stump in eroded blanket bog 2.5 to $3 \mathrm{~m}$ thick above Caochan Dubh a' Chadha, alt, +560m (57 08 $8^{\prime} 23^{\prime \prime} \mathrm{N}, 3^{\circ} 41^{\prime} 11^{\prime \prime}$ W). Coll 1975 by L Beyens and D K Ferguson. Comment (DKF): stump, $14 \mathrm{~cm}$ in diam excluding bark, underlain by $40 \mathrm{~cm}$ peat. While growth was slow (growth rings frequently no more than $0.3 \mathrm{~mm}$ wide and, at most, $1.8 \mathrm{~mm}$ wide) tree lived at least $160 \mathrm{yr}$. Age determination is based on cross-sec covering complete time span.

ANTW-269. Site 12-2, Sample 20

$4450 \pm 140$

Root from pine stump in eroded blanket bog 2.5 to $3 \mathrm{~m}$ thick above Caochan Dubh a' Chadha; alt, +560m (57 $\left.08^{\prime} 23^{\prime \prime} \mathrm{N}, 3^{\circ} 41^{\prime} 11^{\prime \prime} \mathrm{W}\right)$. Coll 1975 by L Beyens and D K Ferguson. Comment (DKF): while stump was underlain by $75 \mathrm{~cm}$ peat, age is younger than ANTW-259. Trunk $16 \mathrm{~cm}$ in diam excluding bark.

\section{ANTW-277. Site 3, Sample 21}

$3940 \pm 60$

Root from pine stump overlain by $80 \mathrm{~cm}$ blanket bog between Creagan Dubh and Allt Clais a $\mathrm{a}^{\prime}$ Mhèirlich; alt, $+660 \mathrm{~m}\left(57^{\circ} 08^{\prime} 38^{\prime \prime} \mathrm{N}\right.$, $3^{\circ} 38^{\prime} 40^{\prime \prime} \mathrm{W}$ ). Coll 1975 by D K Ferguson, J and P D'hondt. Comment (DKF): age based on wood between 60 th and 145 th growth rings. Evidence for fire in form of charcoal was found 60 to $80 \mathrm{~cm}$ below surface.

ANTW-278. Site 19, Sample 22

$2670 \pm 65$

Root from pine stump from eroded blanket bog between Allt Ban and Allt na Ciste; alt, $+485 \mathrm{~m}\left(57^{\circ} 09^{\prime} 12^{\prime \prime}\right.$ N, $\left.3^{\circ} 39^{\prime} 15^{\prime \prime} \mathrm{W}\right)$. Coll 1975 by L Beyens and D K Ferguson. Comment (DKF): relatively old age from site no more than $15 \mathrm{~m}$ above present tree-line could indicate tree-line did not extend above $470 \mathrm{~m}$ in recent past. More age determinations are required to confirm this supposition.

\section{ANTW-225. Loon Plage}

\section{France} 30" E). Coll Oct 1976 by R Vantoorne. Con opinion that marine sans posited during Flandrian transgression. 
ANTW-243. Pont des Grenouilles

$1890 \pm 80$

Peat from top of layer 110 to $120 \mathrm{~cm}$ below surface $\left(51^{\circ} \mathrm{N}, 2^{\circ} 16^{\prime} \mathrm{E}\right)$. Coll 1977 by J Sommé. Comment (RV): peat layer from French coastal plain, covered by marine sands with shells (Cardium edule) overlain by a layer with Medieval pottery and a skeleton of Bovideae. Date, pointing to a Sub-Atlantic age, agrees with pollen diagram characterized by continuous Fagus curve.

\section{Malaysia}

ANTW-266. Dengkil Log 11/1, Sample 1

$1945 \pm 110$

Wood, at $700 \mathrm{~cm}$ below surface $\left(2^{\circ} 53^{\prime} 30^{\prime \prime} \mathrm{N}, 101^{\circ} 43^{\prime} \mathrm{E}\right)$. Coll Feb 1977 by B C Batchelor.

ANTW-282. Dengkil Log 11/1, Sample 2

$1700 \pm 95$

Wood, at $700 \mathrm{~cm}$ below surface $\left(2^{\circ} 53^{\prime} 30^{\prime \prime} \mathrm{N}, 101^{\circ} 43^{\prime} \mathrm{E}\right)$. Coll Feb 1977 by B C Batchelor.

\section{ANTW-283. Lombong Sharikat Galian \\ Gangganegara No. 2, Sample G G $25 \quad 8670 \pm 200$}

Wood, from layer 100 to $500 \mathrm{~cm}$ below surface $\left(40^{\circ} 23^{\prime} 45^{\prime \prime} \mathrm{N}, 100^{\circ}\right.$ $35^{\prime}$ 55" E). Coll 1977 by B C Batchelor.

\section{REFERENCES}

Brian, C B, 1976, Studies in late Cenozoic stratigraphy in parts of sundaland as an aid to tin placer exploration in coastal and offshore areas: Geol Soc Malaysia Mtg, Ipoh discussion, pub no. 127, 1976.

Menaker, M, 1964, Radiocarbon dating: a case against the proposed link between river mollusks and soil humus: Science, v 143, p 596-597.

De Moor, G, 1974, De afzetting van Dendermonde en haar betekenis voor de jongkwartair evolutie van de Vlaamse vallei: Natuurwet Tijdschr, v 56, p 45-75.

De Ploey, I, 1961, Morfologie en Kwartair-stratigrafie van de Antwerpse Noorderkempen: Acta Geog Lovaniensia, v 1, p 82-86.

Fastabend, $\mathrm{H}$ and Von Raupach, F, 1961, Zur kenntnis der Plaggenböden in Nordwestdeutschland: Geol Jahrb, v 78, p 139-172.

Janssens, J, 1977, Overzicht van de Pleistocene en Holocene mosflora van België en aangrenzende gebieden in het raam van ecologische en stratigrafische gegevens: Belgium Univ instelling Antwerpen, lic thesis, p 1-48.

Keith, M L, and Anderson, G M, 1963, Radiocarbon dating: fictitious results with mollusk shells: Science, v 141, p 634-637.

1964, Radiocarbon dating of mollusk shells: a reply: Science, v 144, p 890

Longin, R, 1970, Extration du collagène des os fossiles pour leur datation par la méthode du carbone 14: Thèse no. 553, Fac Sci, Univ Lyon, France.

Muckenhausen, E, Scharpenseel, H W, and Pietig, F, 1968: Zum alter des Plaggenesches: Eiszeitalter u Gegenwart, v 19, p 190-196.

Stockmans, F and Vanhoorne, R, 1954, Etude botanique du gisement de tourbe de la région de Pervyze: Mém Inst Royal Sci Nat Belgigue, v 130, p 1-144.

Thommeret, J, 1976, Difficultés d'interprétation des dates C14 mesurées à partir des coquilles marines: 9th UISPP cong, Nice, p 160-169.

Vanhoorne, R and Van Dongen, W, 1976, Antwerp University radiocarbon dates I: Radiocarbon, v 18, p 151-160.

Vanhoorne, R and Van Strydonck, M, 1977, Antwerp University radiocarbon dates II: Radiocarbon, v 19, p 383-388.

Wyld, G E A, 1970, Statistical conference in liquid scintillation counting, in Bransome, E D, Jr, ed, The current status of liquid scintillation counting: New York, Grune and Stratton, p 69-75. 